tidligere fortolkning, fordi der betones en kontinuitet mellem vores første natur og vores anden natur. Natur-videnskaben er en del af udviklingen hvorved vi som dyr (første natur) forstår os selv som dyr (anden natur) og dermed giver os en viden om os selv som ånd som det hedder i citatet. At afskrive den første naturs vigtighed i Hegels system, fører meget let til en dualisme, mellem ånd/socialitet og natur, der ikke er i Hegels ånd (eller natur). Hermed har jeg forhåbentlig anskueliggjort, om end noget groft, at Pinkard prøver at rykke Hegels filosofi væk fra en overbetoning af socialiteten til at rehabilitere naturen og naturfilosofien (på god Deweyansk vis) som en væsentlig del af Hegels system. Hvilket harmonerer glimrende med Hegels egen påstand om, at han er på materialitetens side frem for en (inter-)subjektiv idealisme, hvis han skulle vælge.

Når det er sagt, så mangler man en diskussion af naturbegrebet $i$ andre traditioner for fortolkning af Hegel. Kort kan nævnes Kojeves berømte forelæsninger i Frankrig, som Lacan som bekendt sad ved og som trækker tråde op til Zizeks nye Hegel-bog. Eller Markus Gabriels forsøg på at revitalisere den tyske idealisme ved blandt andet at bringe amerikanske fortolkninger af Hegel i dialog med tyske.
Desuden kunne denne anmelder godt have ønsket en mere historisk perspektivering $\mathrm{i}$ forhold til Schelling, for hvem naturbegrebet er helt centralt.

Bo Allesoe

Christensen

\section{Autenticiteten og det æstetiske}

Jorgen Debs: Det autentiske. Fortallinger om nutidens kunstbegreb, Forlaget Vandkunsten, 2012 , 216 sider, 229 kr.

Med Det autentiske har Jørgen Dehs begået en hvad udseendet angår pamfletlignende lille bog, hvis indhold imidlertid er vægtigt og fortjener opmærksomhed. Det betyder ikke, at der er ikke er væsentlige indvendinger mod projektet og bogen som sådan. Men bestræbelsen på at vise, hvorledes forestillingen om det autentiske har fungeret som et ideologisk program i kunsten gennem hele moderniteten er $i$ sit udgangspunkt yderst interessant. Hvis man går til bogen med et håb om at blive klogere på, hvad autenticitet og det autentiske er bliver man skuffet, for som Dehs fornuftigt indskærper $i$ indledningen, så handler projektet ikke om at tilføre dette begreb teoretisk substans og give en opskrift på auten- 
ticiteten. Dette er ifølge forfatteren ikke muligt, idet begrebet dækker over et hyperkomplekst fænomen, der ikke sådan lader sig indfange. Det autentiske er en betegnelse vi bruger om noget, der er helt igennem xgte, godt og rigtigt - det vil sige noget der er nøjagtigt hvad det giver sig ud for at være. Og det er - som Dehs påpeger - noget vi strengt taget kun kender gennem dets negative modsætning: det kunstige, løgnagtige, iscenesatte osv.

Det kan på mange måder synes paradoksalt, at forestillingen om det autentiske gennem de seneste godt 250 år er blevet vævet uløseligt sammen med kunstbegrebet, idet kunst og kulturprodukter qua deres modus som noget fremstillet eller iscenesat principielt set påberåber sig noget, der ikke lader sig fremstille. Forklaringen skal selvfølgelig søges i modernitetens tragiske bevægelse fra det sakrale til det sekulære, der igen og igen sladrer om en sakral 'rest' i kunsten og moderne forestillinger, bevægelser og idékomplekser. Autenticiteten er den sakrale rest, som kunsten ikke kan undslippe, heller ikke selvom den gang på gang er blevet benægtet $\mathrm{i}$ de avantgardistiske kunstbevægelser; selve forestillingen om det autentiske indtager $\mathrm{i}$ avantgarden en væsentlig plads, om det så er som negativ klangbund. Her for- mulerer Dehs en væsentlig pointe: nemlig at det er en god ide at nære en kritisk mistro til alt, hvad der påberåber sig at være autentisk - og kunne man tilføje - til alt, hvad der påberåber sig at være inautentisk. I et indledende kapitel om Kierkegaard redegør Dehs således for autenticitetens filosofiske flanker til troen og til den kontemplative tilstand, som hos grækerne gik under betegnelsen ataraxia. Det vil sige en tilstand, hvor artikuleret viden ikke er relevant og hvor vor kognitive virksomhed suspenderes. Autenticiteten er netop det der ikke kan begribes og ikke reduceres til en rent begrebsligt artikuleret størrelse. Det er således ikke muligt at operere med et absolut autenticitetsbegreb. Med Kant understreger Dehs, at autenticitet er noget der opleves som en kvalitet $v i$ tilskriver et værk, en samlivsform eller bestemt måde at handle eller forvalte tilværelsen på.

Dehs' bog former sig som et nedslag i en række æstetiske fænomener, kunsthistoriske udviklinger og forfatterskaber, hvis navne er uløseligt knyttet til temaet: Kant, Kierkegaard, Rousseau, Benjamin, Adorno, Heidegger, Taylor m.fl. som læses ind $\mathrm{i}$ en række forskellige kontekster eller komplekser, der rummer en bestemt forståelse af autenticitet: Natur, geni, mime- 
sis, det sublime, autonomi, kulturel uskyld og ideen om det nye. Vi får således bogen igennem serveret en række forskellige ord for autenticitet og en beskrivelse af dens mangfoldige aspekter. Dehs' projekt er ikke semantisk $\mathrm{i}$ den forstand at han eftersporer selve begrebets opdukken hos forskellige tænkere. Hver gang han introducerer en tænker forsikrer han, at selvom vedkommende ikke anvendte selve ordet autenticitet, så kan hans filosofi anskues som en lang refleksion over temaet. Det er en anelse problematisk, at denne semantiske flade fuldstændigt negligeres. For eksempel havde det været interessant med refleksioner over det forhold, at når begrebet endelig begynder at dukke op (hos tyske tænkere), så går det ikke under navnet autenticitet, men "Eigentlichkeit" som det jo hedder hos Adorno i hans angreb på netop den autenticitetsjargon, som han sporer hos blandt andre Heidegger og eksistensteologerne i mellemkrigsårene, og som for Adorno at se er baseret på en misforstået søgen efter det absolutte, der applikeret på det politiske - som den jo rent faktisk blev i mellemkrigstidens fascisme - tilfører det subjekt, der anvender termen 'autentisk' al for stor magt.

Bogen rummer dog flere stærke pointer, som f.eks. denne, der dukker op i et glimrende kapitel om Rousseau, at hver gang der er højkonjunktur for begreber som "uskyld", "naturlighed" og "egentlighed", så er det tegn på emfatiske erfaringer af det modsatte $i$ samtiden. Her er det på sin plads at minde om Rousseaus påpegning $\mathrm{af}$, at selvom det før-kulturelle (autentiske) menneske er en konstruktion og en projektion, så kan det være en produktiv sådan, fordi den skærper opmærksomheden mod et sted hinsides de kulturelle selvfølgeligheder, hvor tingene kunne være anderledes.

Det autentiske er en historik over forskellige positioner eller idekomplekser, der ligger til grund for nutidens forståelse af kunst, mere end den er en fortælling om nutidens kunst, som overskriften ellers signalerer. Bogen igennem træder Dehs' egentlige ærinde også tydeligere frem: I stedet for at handle om autenticitet og det autentiske bliver bogens hovedperson æstetikken og det æstetiske. Dehs vil fremstille, hvorledes æstetikken udgør et enestående metodisk greb til at teoretisere kvalificeret over emnet autenticitet og $\mathrm{i}$ en bredere kontekst i forlængelse af Kants æstetik og fænomenologien, at "bidrage til at tydeliggøre det frirum, æstetikken søger at etablere $\mathrm{i}$ forhold til den videnskabelig ratio" (s. 48). 
Til slut bør nævnes som et egentligt kritikpunkt en efter min smag lidt for frimodig omgang med filosofien. F.eks. omtales Rousseau som "ham med tilbage til naturen" (s. 65) - det kan selvfølgelig i sig selv være komisk og lidt af en smagssag om man synes den præsentation er velvagt (ironi eller ej), men når Dehs skriver, at Kant og Baumgartens æstetiske indramning af kunstbegrebet med god vilje kan betragtes som en "forløber" for den aktuelle oplevelsesøkonomi ja så savner jeg ganske enkelt flere argumenter for at kunne mobilisere en god vilje. Endelig er det grænsende til det pinagtige, når Dehs omtaler Kant og Baumgarten som "de to 1700-tals-filosoffer fra Königsberg i Østpreussen" (s. 32). Et enkelt Wikipedia-opslag bekræfter, at Baumgarten blev født i Berlin, døde i Frankfurt an der Oder og gennem hele sin universitetskarriere var ansat ved universitetet i Halle. Formentlig har han aldrig sat sine ben i Königsberg hos kollegaen Kant. Når disse indvendinger er gjort anbefales bogen til alle, der har interess $i$ at reflektere over det autentiskes uløselige forbindelse til ikke blot kunsten og det xstetiske men til en række moderne discipliner og ideers selvforståelse.

Rikke Alberg Peters 